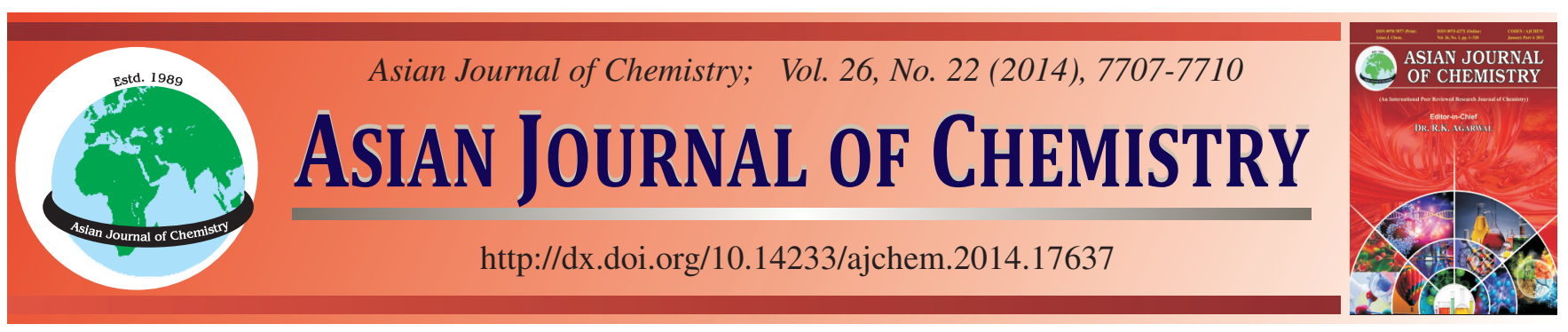

\title{
Synthesis, Characterization and Crystal Structures of Hydrazone Compounds Derived from Cyanoacetohydrazide
}

\author{
Wei-Ming Zhang ${ }^{1, *}$, ShaO-Song Qian ${ }^{2}$ and Zhonglu You ${ }^{3}$
}

\author{
${ }^{1}$ Nanjing Institute for the Comprehensive Utilization of Wild Plant, Nanjing 210042, P.R. China \\ ${ }^{2}$ School of Life Sciences, Shandong University of Technology, Zibo 255049, P.R. China \\ ${ }^{3}$ Department of Chemistry and Chemical Engineering, Liaoning Normal University, Dalian 116029, P.R. China \\ *Corresponding authors: E-mail: youzhonglu@126.com
}

\begin{abstract}
Two new hydrazone compounds, 2-cyano- $N$ '-(3-ethoxy-2-hydroxybenzylidene)acetohydrazide (1) and 2-cyano-N'-(2-methoxybenzylidene)acetohydrazide (2), were prepared and structurally characterized by elemental analysis, IR and UV-visible spectra and single crystal $\mathrm{X}$-ray determination. Compound 1 crystallizes as monoclinic space group $\mathrm{P} 2_{1} / \mathrm{c}$, with unit cell dimensions $\mathrm{a}=19.573(7) \AA, \mathrm{b}=9.620(4)$ $\AA, c=13.731(5) \AA, \beta=110.372(4)^{\circ}, V=2423.8(15) \AA^{3}, Z=8, R_{1}=0.1047$ and $w R_{2}=0.2767$. Compound 2 crystallizes as monoclinic space group $\mathrm{P} 2{ }_{1} / \mathrm{c}$, with unit cell dimensions $\mathrm{a}=4.503(2) \AA, \mathrm{b}=10.066(3) \AA, \mathrm{c}=24.435(3) \AA, \beta=95.29(2)^{\circ}, \mathrm{V}=1103.0(5) \AA^{3}, \mathrm{Z}=4$, $\mathrm{R}_{1}=0.0430$ and $\mathrm{wR}_{2}=0.0978$. Crystal of the compounds are stabilized by hydrogen bonds and $\pi \cdots \pi$ interactions.
\end{abstract}

Keywords: Hydrazone, Cyanoacetohydrazide, Crystal structure, Hydrogen bonding.

\section{INTRODUCTION}

Hydrazones are a kind of compounds bearing the typical $-\mathrm{C}(\mathrm{O})-\mathrm{NH}-\mathrm{N}=\mathrm{CH}$ - groups, which can easily be prepared by the condensation reactions of carbonyl-containing compounds with hydrazines. The compounds have been attracted considerable attention for their wide range of biological activities, such as antibacterial ${ }^{1,2}$, antifungi ${ }^{3}$, antitumor ${ }^{4,5}$, antiinflammatory ${ }^{6,7}$, and cytotoxic ${ }^{8,9}$. In recent years, a large number of hydrazones derived from benzohydrazides with various aldehydes have been reported ${ }^{10-13}$. However, those derived from cyanoacetohydrazide are less reported ${ }^{14,15}$. In the present paper, two new hydrazone compounds, 2-cyano- $N$ '-(3-ethoxy-2hydroxybenzylidene)acetohydrazide (1) and 2-cyano- $N$ '-(2methoxybenzylidene)acetohydrazide (2), are presented.

\section{EXPERIMENTAL}

Starting materials, reagents and solvents with AR grade were purchased from commercial suppliers and used without further purification. Elemental analyses were performed on a Perkin-Elmer $24{ }^{\circ} \mathrm{C}$ elemental analyzer. IR spectra were recorded on a Jasco FT/IR-4000 spectrometer as $\mathrm{KBr}$ pellets in the 4000-400 $\mathrm{cm}^{-1}$ region. UV-visible spectra were recorded on a Lambda 900 spectrometer with methanol as solvent.

Synthesis of 2-cyano- $N$ '-(3-ethoxy-2-hydroxybenzylidene)acetohydrazide (1): 3-Ethoxysalicylaldehyde (1 mmol, $0.166 \mathrm{~g})$ and cyanoacetohydrazide ( $1 \mathrm{mmol}, 0.099 \mathrm{~g})$ were mixed in methanol and stirred at room temperature for $1 \mathrm{~h}$. The solvent was evaporated to obtain colourless crystalline product of 1, which was washed with methanol and dried in air. Yield: $87 \%$. Single crystals of $\mathbf{1}$ suitable for X-ray diffraction were obtained by recrystallization of the product in methanol. m.p. $183-185^{\circ} \mathrm{C}$. Anal. calcd. for $\mathrm{C}_{12} \mathrm{H}_{13} \mathrm{~N}_{3} \mathrm{O}_{3}: \mathrm{C}$, 58.3; H, 5.3; N, 17.0; Found: C, 58.2; H, 5.3; N, $16.8 \%$. IR data $\left(\mathrm{KBr}, \mathrm{v}_{\max }, \mathrm{cm}^{-1}\right): 3326(\mathrm{w}), 3163(\mathrm{w}), 1679(\mathrm{~s}), 1619$ (m), $1471(\mathrm{w}), 1413$ (m), $1370(\mathrm{w}), 1312(\mathrm{w}), 1255$ (m), 1170 (w), $1051(\mathrm{w}), 963(\mathrm{w}), 755(\mathrm{~m}), 572(\mathrm{w}), 540(\mathrm{w})$.

Synthesis of 2-cyano-N'-(2-methoxybenzylidene)acetohydrazide (2): 2-Methoxybenzaldehyde (1 mmol, 0.136 $\mathrm{g})$ and cyanoacetohydrazide ( $1 \mathrm{mmol}, 0.099 \mathrm{~g})$ were mixed in methanol and stirred at room temperature for $1 \mathrm{~h}$. The solvent was evaporated to obtain colourless crystalline product of $\mathbf{2}$, which was washed with methanol and dried in air. Yield: $79 \%$. Single crystals of $\mathbf{2}$ suitable for X-ray diffraction were obtained by recrystallization of the product in methanol. m.p. 149-151 ${ }^{\circ} \mathrm{C}$. Anal. calcd. for $\mathrm{C}_{11} \mathrm{H}_{11} \mathrm{~N}_{3} \mathrm{O}_{2}$ : C, 60.8; H, 5.1; N, 19.3; Found: C, 61.0; H, 5.0; N, $19.4 \%$. IR data $\left(\mathrm{KBr}, \mathrm{v}_{\max }, \mathrm{cm}^{-1}\right): 3197$ (w), 1678 (s), 1623 (m), 1475 (w), 1419 (m), 1301 (w), 1257 (m), 1034 (w), 966 (w), 755 (m), 558 (w).

Data collection, structural determination and refinement: Diffraction intensities for the compounds were collected at 298(2) K using a Bruker D8 VENTURE PHOTON diffractometer with $\mathrm{MoK}_{\alpha}$ radiation $(\lambda=0.71073 \AA)$. The collected 
data were reduced using the SAINT program ${ }^{16}$, and multi-scan absorption corrections were performed using the SADABS program $^{17}$. The structures were solved by direct methods and refined against $\mathrm{F}^{2}$ by full-matrix least-squares methods using the SHELXTL ${ }^{18}$. All of the non-hydrogen atoms were refined anisotropically. The amino $\mathrm{H}$ atoms were located in difference Fourier maps and refined isotropically, with $\mathrm{N}-\mathrm{H}$ distances restrained to $0.90(1) \AA$. All other $\mathrm{H}$ atoms were placed in idealized positions and constrained to ride on their parent atoms. The crystallographic data for the compounds are summarized in Table-1. Selected bond values are listed in Table-2. Hydrogen bonding information is given in Table-3.

\begin{tabular}{|c|c|c|}
\hline \multicolumn{3}{|c|}{$\begin{array}{c}\text { TABLE-1 } \\
\text { CRYSTALLOGRAPHIC AND EXPERIMENTAL } \\
\text { DATA FOR THE COMPOUNDS }\end{array}$} \\
\hline Compound & 1 & 2 \\
\hline m.f. & $\mathrm{C}_{12} \mathrm{H}_{13} \mathrm{~N}_{3} \mathrm{O}_{3}$ & $\mathrm{C}_{11} \mathrm{H}_{11} \mathrm{~N}_{3} \mathrm{O}_{2}$ \\
\hline m.w. & 247.2 & 217.2 \\
\hline $\mathrm{T}(\mathrm{K})$ & $298(2)$ & $298(2)$ \\
\hline Crystal shape/colour & block/colourless & block/colourless \\
\hline Crystal size $\left(\mathrm{mm}^{3}\right)$ & $0.13 \times 0.07 \times 0.07$ & $0.12 \times 50.10 \times 0.08$ \\
\hline Crystal system & Monoclinic & Monoclinic \\
\hline Space group & $\mathrm{P} 2_{1} / \mathrm{c}$ & $\mathrm{P} 2_{1} / \mathrm{c}$ \\
\hline $\mathrm{a}(\AA)$ & $19.573(7)$ & $4.503(2)$ \\
\hline $\mathrm{b}(\AA)$ & $9.620(4)$ & $10.066(3)$ \\
\hline c $(\AA)$ & $13.731(5)$ & $24.435(3)$ \\
\hline$\beta\left(^{\circ}\right)$ & $110.372(4)$ & $95.29(2)$ \\
\hline$V\left(\AA^{3}\right)$ & $2423.8(15)$ & $1103.0(5)$ \\
\hline $\mathrm{Z}$ & 8 & 4 \\
\hline $\mathrm{D}_{\mathrm{c}}\left(\mathrm{g} \mathrm{cm}^{-3}\right)$ & 1.355 & 1.308 \\
\hline$\mu\left(\operatorname{MoK}_{\alpha}\right)\left(\mathrm{mm}^{-1}\right)$ & 0.100 & 0.093 \\
\hline $\mathrm{F}(000)$ & 1040 & 456 \\
\hline Reflections collected & 12033 & 4101 \\
\hline Unique reflections & 4261 & 1660 \\
\hline $\begin{array}{l}\text { Observed reflections } \\
(I \geq 2 \sigma(I))\end{array}$ & 2619 & 1002 \\
\hline Parameters & 335 & 149 \\
\hline Restraints & 2 & 1 \\
\hline $\begin{array}{l}\text { Min. and max. } \\
\text { transmission }\end{array}$ & $0.9871,0.9930$ & $0.9889,0.9926$ \\
\hline Goodness-of-fit on $\mathrm{F}^{2}$ & 1.022 & 0.862 \\
\hline $\mathrm{R}_{1}, \mathrm{wR}_{2}[\mathrm{I} \geq 2 \sigma(\mathrm{I})]^{\mathrm{a}}$ & $0.1047,0.2767$ & $0.0430,0.0978$ \\
\hline $\mathrm{R}_{1}, \mathrm{wR}_{2}(\text { all data })^{\mathrm{a}}$ & $0.1483,0.3143$ & $0.0685,0.1056$ \\
\hline $\begin{array}{l}\text { Large diff. peak and } \\
\text { hole }\left(\mathrm{e}^{-3}\right)\end{array}$ & $0.489,-0.338$ & $0.096,-0.136$ \\
\hline
\end{tabular}

\begin{tabular}{cccc}
\hline \multicolumn{5}{c}{ TABLE-2 } \\
SELECTED BOND DISTANCES $(\AA)$ AND BOND \\
ANGLES $\left(^{\circ}\right)$ FOR THE COMPOUNDS \\
\hline \multicolumn{4}{c}{ Compound 1 } \\
\hline N1-C7 & $1.293(6)$ & N1-N2 & $1.379(5)$ \\
N2-C8 & $1.354(6)$ & N4-C19 & $1.283(6)$ \\
N4-N5 & $1.372(5)$ & N5-C20 & $1.339(6)$ \\
C7-N1-N2 & $115.5(4)$ & C8-N2-N1 & $117.4(4)$ \\
C19-N4-N5 & $117.1(4)$ & C20-N5-N4 & $118.6(4)$ \\
\hline \multicolumn{5}{c}{ Compound 2 } \\
\hline N1-C8 & $1.275(2)$ & N1-N2 & $1.371(2)$ \\
N2-C9 & $1.326(2)$ & - & - \\
C8-N1-N2 & $113.04(17)$ & C9-N2-N1 & $122.07(16)$ \\
\hline \multicolumn{5}{c}{}
\end{tabular}

\section{RESULTS AND DISCUSSION}

Compounds $\mathbf{1}$ and $\mathbf{2}$ were readily synthesized by reaction of 1:1 molar ratio of cyanoacetohydrazide with 3-ethoxysalicylaldehyde and 2-methoxybenzaldehyde, respectively, in methanol at room temperature. Single crystals of the compounds, suitable for X-ray diffraction, were obtained by slow evaporation of the solutions containing the compounds in air. The compounds have been characterized by elemental analyses and IR and UV-visible spectra. Structures of the compounds were further confirmed by single crystal X-ray crystallography.

Structure description of the compounds: Figs. 1 and 2 give perspective views of compounds $\mathbf{1}$ and $\mathbf{2}$ with atomic labeling systems. X-ray crystallography reveals that the compounds are similar hydrazone species. In compound $\mathbf{1}$, the asymmetric unit contains two independent molecules. All the hydrazone molecules of the compounds adopt E configuration with respect to the methylidene units. The distances of the methylidene bonds, ranging from $1.27 \AA$ to $1.30 \AA$, confirm them as typical double bonds. The shorter distances of the $\mathrm{C}-\mathrm{N}$ bonds and the longer distances of the $\mathrm{C}=\mathrm{O}$ bonds for the $-\mathrm{C}(\mathrm{O})-\mathrm{NH}$ - units than usual, suggests the presence of conjugation effects in the molecules. The remaining bond lengths in the compounds are comparable to each other and are within normal values ${ }^{14,15}$.

In the crystal structure of $\mathbf{1}$, molecules are linked through $\mathrm{N}-\mathrm{H} \cdots \mathrm{O}, \mathrm{O}-\mathrm{H} \cdots \mathrm{N}, \mathrm{C}-\mathrm{H} \cdots \mathrm{O}$ and $\mathrm{C}-\mathrm{H} \cdots \mathrm{N}$ hydrogen bonds, to form layers parallel to the $b c$ plane (Fig. 3). In the crystal structure of 2 , molecules are linked through $\mathrm{N}-\mathrm{H} \cdots \mathrm{O}$ and $\mathrm{C}-\mathrm{H} \cdots \mathrm{O}$ hydrogen bonds, to form chains running along the a

TABLE-3

HYDROGEN BOND DISTANCES $(\AA ̊)$ AND BOND ANGLES $\left({ }^{\circ}\right)$ FOR THE COMPOUNDS

\begin{tabular}{|c|c|c|c|c|}
\hline D-H $\cdots A$ & $d(D-H)$ & $\mathrm{d}(\mathrm{H} \cdots \mathrm{A})$ & $\mathrm{d}(\mathrm{D} \cdots \mathrm{A})$ & Angle $(\mathrm{D}-\mathrm{H} \cdots \mathrm{A})$ \\
\hline \multicolumn{5}{|c|}{ Compound 1} \\
\hline $\mathrm{N} 5-\mathrm{H} 5 \cdots \mathrm{O}^{\mathrm{i}}$ & 0.90 & $2.04(3)$ & $2.892(6)$ & $157(6)$ \\
\hline $\mathrm{N} 2-\mathrm{H} 2 \cdots \mathrm{O} 3^{\mathrm{ii}}$ & 0.90 & $1.98(2)$ & $2.863(5)$ & $169(6)$ \\
\hline $\mathrm{O} 4-\mathrm{H} 4 \cdots \mathrm{N} 4$ & 0.82 & 1.88 & $2.598(5)$ & 145 \\
\hline $\mathrm{O} 1-\mathrm{H} 1 \cdots \mathrm{N} 1$ & 0.82 & 1.87 & $2.585(5)$ & 146 \\
\hline $\mathrm{C} 7-\mathrm{H} 7 \cdots \mathrm{N} 3^{\mathrm{ii}}$ & 0.93 & 2.57 & 3.430 & 154 \\
\hline $\mathrm{C} 9-\mathrm{H} 9 \mathrm{~A} \cdots \mathrm{O} 3^{\mathrm{ii}}$ & 0.97 & 2.56 & 3.278 & 131 \\
\hline $\mathrm{C} 19-\mathrm{H} 19 \cdots \mathrm{N} 6^{\mathrm{i}}$ & 0.93 & 2.51 & 3.403 & 160 \\
\hline $\mathrm{C} 21-\mathrm{H} 21 \mathrm{~B} \cdots \mathrm{O}^{\mathrm{i}}$ & 0.97 & 2.56 & 3.212 & 125 \\
\hline \multicolumn{5}{|c|}{ Compound 2} \\
\hline $\mathrm{N} 2-\mathrm{H} 2 \cdots \mathrm{O} 2^{\mathrm{iii}}$ & 0.90 & $1.97(1)$ & $2.861(2)$ & $174(2)$ \\
\hline $\mathrm{C} 10-\mathrm{H} 10 \mathrm{~B} \cdots \mathrm{O} 2^{\mathrm{iv}}$ & 0.97 & 2.47 & 3.341 & 150 \\
\hline
\end{tabular}

Symmetry codes: i) $2-\mathrm{x},-1-\mathrm{y}, 2-\mathrm{z}$; ii) $1-\mathrm{x},-1-\mathrm{y},-\mathrm{z}$; iii) $2-\mathrm{x}, 3 / 2+\mathrm{y}, 3 / 2-\mathrm{z}$; iv) $-1+\mathrm{x}, \mathrm{y}, \mathrm{z}$ 
TABLE-4

PARAMETERS BETWEEN THE PLANES OF THE COMPLEX

\begin{tabular}{|c|c|c|c|c|}
\hline $\mathrm{Cg}$ & $\begin{array}{l}\text { Distance between ring } \\
\text { centroids }(\AA)\end{array}$ & Dihedral angle $\left({ }^{\circ}\right)$ & $\begin{array}{l}\text { Perpendicular distance of } \\
\operatorname{Cg}(\mathrm{I}) \text { on } \operatorname{Cg}(\mathrm{J})(\AA)\end{array}$ & $\begin{array}{l}\text { Perpendicular distance of } \\
\operatorname{Cg}(\mathrm{J}) \text { on } \operatorname{Cg}(\mathrm{I})(\AA)\end{array}$ \\
\hline \multicolumn{5}{|c|}{ Compound 1} \\
\hline $\mathrm{Cg} 1-\mathrm{Cg} 2^{\mathrm{v}}$ & 4.912 & 66 & -1.254 & 4.806 \\
\hline \multicolumn{5}{|c|}{ Compound 2} \\
\hline $\mathrm{Cg} 3-\mathrm{Cg} 3^{\text {vi }}$ & 4.503 & 0 & 3.394 & -3.394 \\
\hline
\end{tabular}

Symmetry codes: (v): x, 1/2-y, $-1 / 2+z$; (vi): $-1+\mathrm{x}, \mathrm{y}, \mathrm{z} . \mathrm{Cg} 1$ and $\mathrm{Cg} 2$ are the centroids of C13-C18 and $\mathrm{C} 1-\mathrm{C} 6$ benzene rings of $1 . \mathrm{Cg} 3$ is the centroid of C1-C6 benzene ring of 2

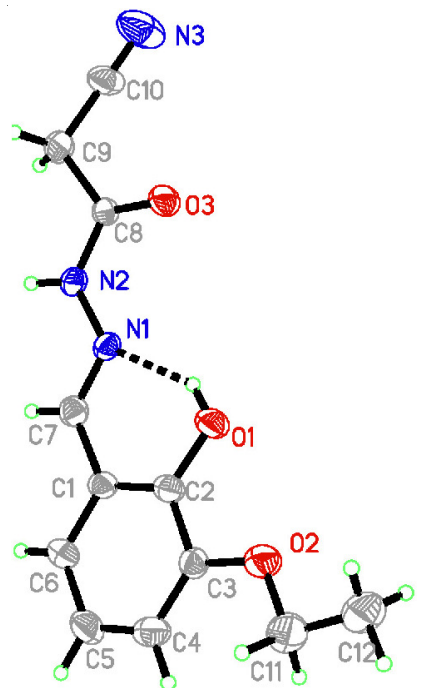

Fig. 1. A perspective view of the molecular structure of $\mathbf{1}$ with the atom labeling scheme. Thermal ellipsoids are drawn at the $30 \%$ probability level. Hydrogen bonds are shown as dashed lines

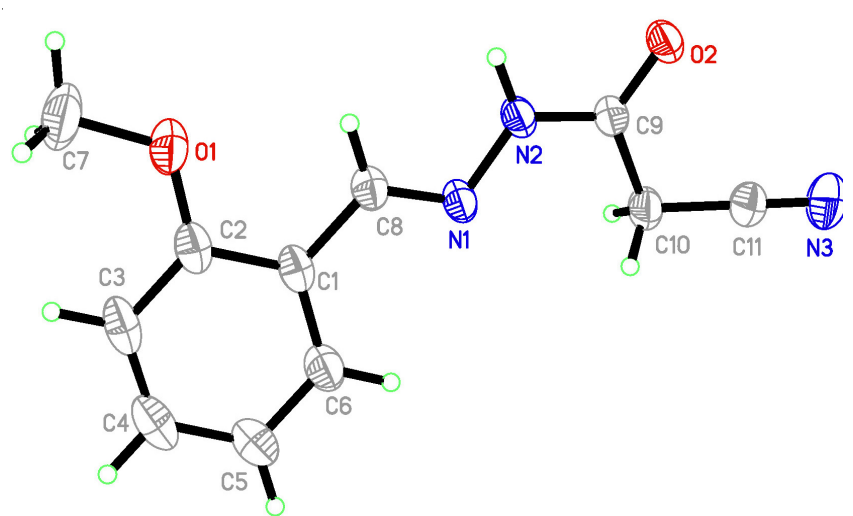

Fig. 2. A perspective view of the molecular structure of $\mathbf{2}$ with the atom labeling scheme. Thermal ellipsoids are drawn at the $30 \%$ probability level

axis direction (Fig. 4). In addition, in both compounds, there exist $\pi \cdots \pi$ interactions (Table- 4 ).

IR and UV-visible spectra: The characteristic intense bands at about $1678 \mathrm{~cm}^{-1}$ are generated by the $\mathrm{v}(\mathrm{C}=\mathrm{O})$ vibrations, whereas the bands at about $1620 \mathrm{~cm}^{-1}$ are assigned to the $v(C=N)$ vibrations. In the spectrum of $\mathbf{1}$, there is a broad absorption centered at $3326 \mathrm{~cm}^{-1}$, which can be attributed to the hydrogen-bonded phenol group. The sharp bands in the range $3200-3160 \mathrm{~cm}^{-1}$ are assigned to the $\mathrm{v}(\mathrm{N}-\mathrm{H})$ vibrations. The methanolic solutions of the compounds with concentration of $10^{-5} \mathrm{~mol} \mathrm{~L}^{-1}$ have been used to record the electronic spectra (Fig. 5). There are two major absorptions with the maximum

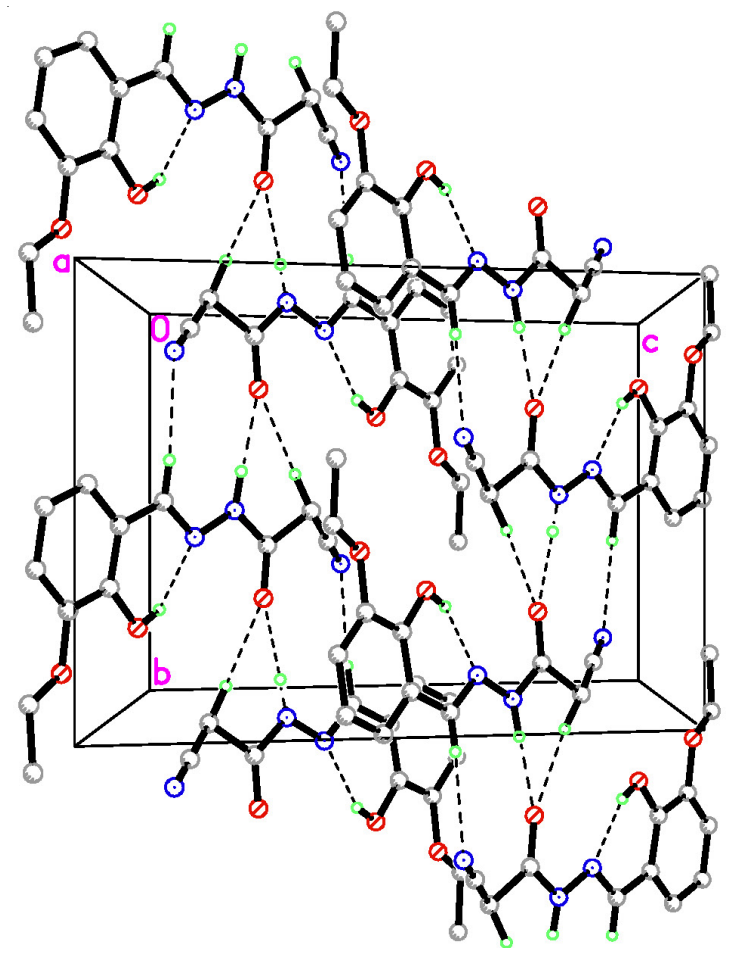

Fig. 3. Molecular packing structure of $\mathbf{1}$, viewed along the a-axis direction. Hydrogen bonds are shown as dashed lines

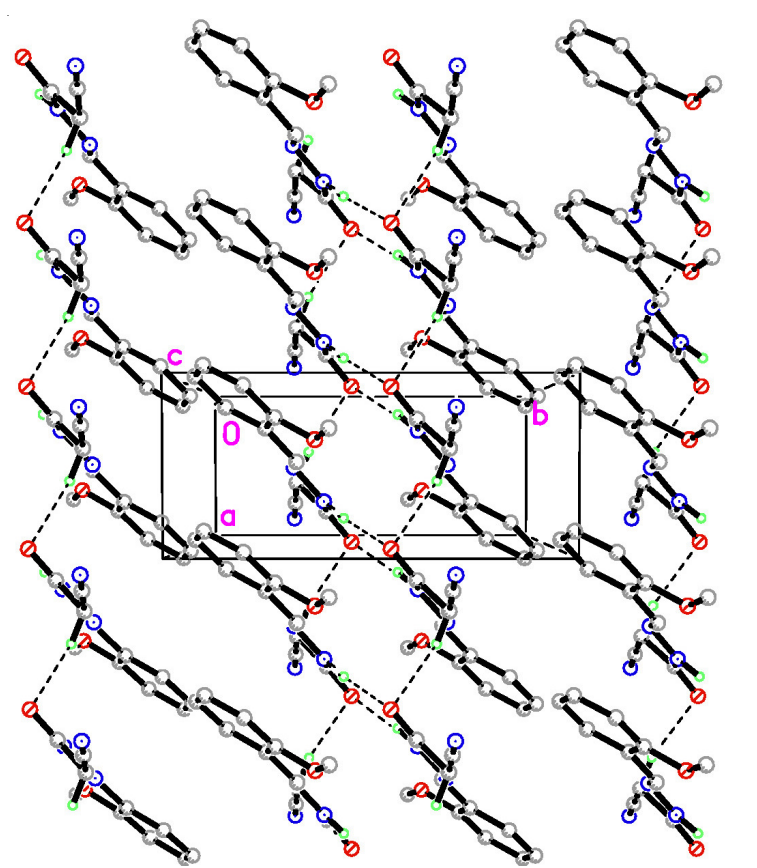

Fig. 4. Molecular packing structure of 2, viewed along the c-axis direction. Hydrogen bonds are shown as dashed lines 
absorptions at 225 and $288 \mathrm{~nm}$ for $\mathbf{1}$ and three major absorptions with the maximum absorptions at 213, 277 and $317 \mathrm{~nm}$ for 2 . The first absorption in each spectrum can be assigned to $\pi-\pi *$ transition and the other absorptions can be assigned to $\mathrm{n}-\pi *$ transition.

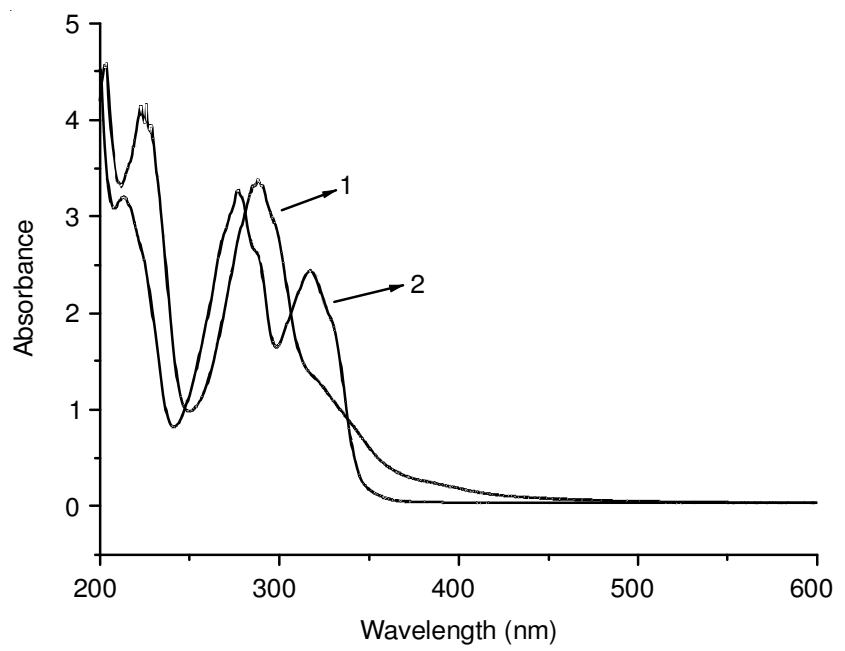

Fig. 5. UV-visible spectra of the compounds

Supplementary information: CCDC-992539 for $\mathbf{1}$ and 992540 for $\mathbf{2}$ contain the supplementary crystallographic data for this paper. These data can be obtained free of charge at http://www.ccdc.cam.ac.uk/const/retrieving.html or from the
Cambridge Crystallographic Data Centre (CCDC), 12 Union Road, Cambridge CB2 1EZ, UK; fax: +44(0)1223-336033 or e-mail:deposit@ccdc.cam.ac.uk.

\section{REFERENCES}

1. D.W. Banner and P. Hadvary, J. Biol. Chem., 266, 20085 (1991).

2. E. Sandstrom, Drugs, 38, 417 (1989).

3. P.H. Chan, J.W. Schmidley, R.A. Fishman and S.M. Longar, Neurology, 34, 315 (1984).

4. H.S.D. Naeff, M.C.R. Franssen and H.C. van der Plas, Recl. Trav. Pay-B, 110, 139 (1991).

5. P. Pacher, A. Nivorozhkin and C. Szabo, Pharmacol. Rev., 58, 87 (2006).

6. A.A. Fatokun, T.W. Stone and R.A. Smith, Neurosci. Lett., 416, 34 (2007).

7. R.K. Robins, G.R. Revankar, D.E. O'Brien, R.H. Springer, T.N.A. Albert, K. Senga, J.P. Miller and D.G. Streeter, J. Heterocycl. Chem., 22, 601 (1985).

8. K. Okamoto, B.T. Eger, T. Nishino, E.F. Pai and T. Nishino, Nucleos. Nucleot. Nucl. Acids, 27, 888 (2008).

9. A. Haberland, H. Luther and I. Schimke, Agents Actions, 32, 96 (1991).

10. M.F. Simeonov, F. Fulop, R. Sillanpaa and K. Pihlaja, J. Org. Chem., 62, 5089 (1997).

11. S. Ianelli and M. Carcelli, J. Chem. Crystallogr., 31, 123 (2001).

12. R. Dinda, P. Sengupta, S. Ghosh, H. Mayer-Figge and W.S. Sheldrick, J. Chem. Soc., Dalton Trans., 4434 (2002).

13. S.-P. Guo, Chinese J. Struct. Chem., 31, 377 (2012).

14. L. Somogyi and A.C. Benyei, Heteroatom Chem., 20, 183 (2009).

15. X. Zhou and J.-J. Ma, J. Chem. Crystallogr., 42, 1138 (2012).

16. Bruker, SMART and SAINT. Bruker AXS Inc., Madison, Wisconsin, USA (2002).

17. G.M. Sheldrick, SADABS. Program for Empirical Absorption Correction of Area Detector, University of Göttingen, Germany (1996).

18. G.M. Sheldrick, Acta Crystallogr. A, 64, 112 (2008). 